\title{
Inhibition of Growth of Chlamydia trachomatis by the Calcium Antagonist Verapamil
}

\author{
By RUTH SHAINKIN-KESTENBAUM, ${ }^{1}$ YEHUDIT WINIKOFF, ${ }^{1}$ \\ RINA KOL, ${ }^{2}$ CIDIO CHAIMOVITZ ${ }^{2}$ AND ISRAEL SAROV ${ }^{3 *}$ \\ ${ }^{1}$ Department of Nephrology, ${ }^{2}$ Institute of Pathology, and ${ }^{3}$ Virology Unit, Soroka Medial Center \\ and Faculty of Health Sciences, Ben-Gurion University of the Negev, Beer Sheva 84105, Israel
}

(Received 9 August 1988; revised 13 February 1989; accepted 22 February 1989)

\begin{abstract}
Treatment of BGM (African Green Monkey kidney) cells with the calcium antagonist Verapamil resulted in a reduced yield of chlamydial infectious particles. The inhibitory effect was concentration-dependent, the maximal effect being achieved at $200 \mu \mathrm{M}$-Verapamil, which produced a $99.99 \%$ reduction of infectious particle yield. Electron microscopy showed that control Chlamydia trachomatis-infected BGM cells contained typical large inclusions in which most of the particles were elementary bodies, whereas Verapamil-treated infected cells contained small inclusions consisting predominantly of reticulate bodies. The findings indicate a possible therapeutic use of this calcium antagonist as an anti-chlamydial drug.
\end{abstract}

\section{INTRODUCTION}

Chlamydia trachomatis, an obligate intracellular bacterium, with a genome of $660 \times 10^{6} \mathrm{Da}$ (Sarov \& Becker, 1968, 1969; Moulder, 1982), is the causative agent of trachoma, inclusion conjunctivitis and lymphogranuloma venereum. It is now well established that certain serovars of $C$. trachomatis (D through $\mathrm{K}$ ) are the most common cause of non-gonococcal urethritis and post-gonococcal urethritis, cervicitis, endometritis, neonatal pneumonitis and epididymitis. Recent studies have also implicated $C$. trachomatis as one of the major causes of pelvic inflammatory disease, which may lead to infertility (reviewed by Ladany \& Sarov, 1985).

Chlamydiae undergo a unique developmental cycle within the host cell. The small $(300 \mathrm{~nm})$ infectious elementary body (EB) characterized by an electron-dense core, enters the host cell by endocytosis and differentiates to a large $(1000 \mathrm{~nm})$ metabolically active reticulate body (RB). The RBs multiply by binary fission and differentiate to the infectious EBs, which are released after host cell lysis (reviewed by Ward, 1983).

In extensive studies with $C$. trachomatis, Ward \& Salari (1982) suggested that $\mathrm{Ca}^{2+}$ ions, among other substances, were important in the control mechanism governing chlamydial infectivity of HeLa cells. Adhesion of chlamydiae to host cells was found to be associated with a flux of $\mathrm{Ca}^{2+}$ across the cell membrane.

Since treatment of chlamydial infection is an important clinical need, the aim of this study was to find out whether the calcium antagonist Verapamil, which is used as a therapeutic agent mainly in cardiovascular disease, would affect $C$. trachomatis growth in cell culture.

\section{METHODS}

Tissue culture. African green monkey kidney (BGM) cells were grown in RPMI 1640 medium, supplemented with $10 \%(\mathrm{v} / \mathrm{v})$ foetal calf serum, $2 \mathrm{mM}$-glutamine, $100 \mathrm{U}$ penicillin ml $\mathrm{m}^{-1}, 100 \mu \mathrm{g}$ streptomycin ml $\mathrm{m}^{-1}$ and $12.5 \mathrm{U}$ mycostatin $\mathrm{ml}^{-1}$ (all purchased from Biological Industries, Beth Haemek, Israel).

Abbreviations: EB, elementary body, RB, reticulate body, IFU, inclusion-forming unit. 
Preparation of infectious, purified, EB particles. C. trachomatis biovar lymphogranuloma venereum (L2/434/Bu) was grown in BGM cells in RPMI 1640 supplemented with $10 \%(\mathrm{v} / \mathrm{v})$ foetal calf serum, $1 \%(\mathrm{w} / \mathrm{v})$ glucose, $0 \cdot 15 \%$ sodium bicarbonate, $2 \mathrm{mM}$-L-glutamine, $100 \mu \mathrm{g}$ streptomycin $\mathrm{ml}^{-1}, 10 \mu \mathrm{g}$ Fungizone $\mathrm{ml}^{-1}$, and $1 \mu \mathrm{g}$ cycloheximide $\mathrm{ml}^{-1}$. Chlamydiae were harvested from BGM monolayers grown in $175 \mathrm{~cm}^{2}$ (basal area) polystyrene flasks (Nunc) as described by Caldwell et al. (1981). Purified EBs were suspended in SPG buffer (0.01 M-sodium phosphate buffer, pH 7.2, containing $0 \cdot 25 \mathrm{M}$-sucrose and $5 \mathrm{mM}$-L-glutamic acid) and stored at $-70^{\circ} \mathrm{C}$ until use.

Effect of Verapamil on the yield of infectious $C$. trachomatis particles in BGM cells. Prior to infection, BGM cells were thoroughly washed with medium free of antibiotics and seeded in 96-well microwell plates (Nunc) at $2.5 \times 10^{4}$ cells per well. After $48 \mathrm{~h}$, the medium was aspirated and the cells were infected with purified $C$. trachomatis at an input multiplicity of infection (m.o.i.) of 1.0 . After $90 \mathrm{~min}$ at $37^{\circ} \mathrm{C}$ for adsorption, the inoculum was removed, cells thoroughly rinsed and fresh medium added (as described above for the preparation of infectious, purified EB). Verapamil (Teva, Jerusalem) was added at various concentrations, either during the $90 \mathrm{~min}$ of the adsorption period only, or after the adsorption period for $45 \mathrm{~h}$ post-infection. At $45 \mathrm{~h}$ after infection, the cells were scraped into their overlaying medium. Duplicate wells were pooled and their contents were frozen at $-70^{\circ} \mathrm{C}$. In order to measure the chlamydial yield, the thawed samples were sonicated for $40 \mathrm{~s}$ (Bransonic sonifier). Tenfold dilutions were prepared in growth medium and titrated in triplicate on BGM cells as described below.

Immunoperoxidase assay for titration of C. trachomatis. C. trachomatis was titrated on HEp-2 cells as described by Shemer \& Sarov (1985). The cells were seeded at $2 \times 10^{4}$ to $3 \times 10^{4}$ cells per well in 96-well microwell plates (Nunc). After $48 \mathrm{~h}$, triplicate $50 \mu \mathrm{l}$ samples of serial 10-fold dilutions of chlamydial inoculum, prepared in growth medium, were added. The plates were fixed $2 \mathrm{~d}$ later with $100 \%$ ethanol and an immunoperoxidase assay (Sarov \& Haikin, 1983) was performed. The final titration results were expressed as inclusion-forming units (IFU) $\mathrm{ml}^{-1}$.

Effect of Verapamil on the number of chlamydial inclusions. Prior to infection, BGM cells were washed, as described above, and were seeded on coverslips in 4-well multidish titration plates (Nunc) at $2 \times 10^{5}$ cells per well. After $48 \mathrm{~h}$, the growth medium was replaced with fresh medium and infected with purified $C$. trachomatis (m.o.i. = 1). After the $90 \mathrm{~min}$ adsorption period, and washing and rinsing, medium with and without various concentrations of Verapamil was added and the BGM cells incubated for $45 \mathrm{~h}$ post-infection. The cells were then fixed with methanol, and stained with Giemsa. Three hundred cells were examined for the presence of chlamydial inclusion bodies by light microscopy.

Effect of Verapamil on DNA synthesis in control cells. BGM cells were grown as described above. After $48 \mathrm{~h}$, the growth medium was replaced with medium without cycloheximide, containing appropriate concentrations of Verapamil and [methyl- $\left.{ }^{3} \mathrm{H}\right]$ thymidine $\left(1 \mu \mathrm{Ci} \mathrm{ml}^{-1}, 37 \mathrm{kBq} \mathrm{ml}^{-1}\right.$; specific activity, $2000 \mu \mathrm{Ci} \mathrm{mol}^{-1}$, $74 \mathrm{MBq} \mathrm{mol}^{-1}$; Nuclear Research Centre, Negev, Israel) was added. After $24 \mathrm{~h}$ and $48 \mathrm{~h}$, TCA precipitates were collected on Millipore filters. Radioactivity was measured in a Packard liquid scintillation spectrophotometer using a toluene-based scintillant (Bio-Lab Ltd, Jerusalem).

Electron microscopy. C. trachomatis-infected cells (m.o.i. $=1$ ), with or without Verapamil added after the adsorption period were prepared for transmission electron microscopy in 4-well plates (Nunc). At $24 \mathrm{~h}$ and $45 \mathrm{~h}$ post-infection, the cells were fixed directly in the original culture wells with $1 \%(\mathrm{w} / \mathrm{v})$ glutaraldehyde and $4 \%(\mathrm{v} / \mathrm{v})$ formaldehyde in $0 \cdot 15 \mathrm{M}$-sodium phosphate buffer, $\mathrm{pH} 7 \cdot 2$, overnight at $4{ }^{\circ} \mathrm{C}$. After dehydration with increasing concentrations of ethanol, the cells were scraped into capsules, and the pellets embedded in Araldite-502 (Luft) and sectioned. Sections were examined with a Philips $201 \mathrm{C}$ electron microscope at $60 \mathrm{kV}$ following staining with uranyl acetate and lead citrate.

\section{RESULTS}

Effect of Verapamil on chlamydial yield. The effect of various concentrations of Verapamil $(50 \mu \mathrm{M}$ to $200 \mu \mathrm{M})$ on $C$. trachomatis yield when it was added post-adsorption to $C$. trachomatisinfected cells is illustrated in Fig. 1. Increasing concentrations of Verapamil resulted in increasing inhibition of chlamydial infectivity, up to a 1000 -fold reduction at $200 \mu \mathrm{M}$-Verapamil. However, when $200 \mu \mathrm{M}$-Verapamil was present throughout the adsorption period only, there was only a threefold inhibition of chlamydial yield at $45 \mathrm{~h}$ post-infection.

Effect of Verapamil on the number of chlamydial inclusions. BGM cells infected with $C$. trachomatis, with and without the addition of Verapamil after adsorption, were examined by light microscopy, $45 \mathrm{~h}$ after infection, for the presence of inclusion bodies following Giemsa staining. Control and $50 \mu \mathrm{M}$-Verapamil-treated cells showed a typical large inclusion in almost every cell. With higher concentrations of Verapamil, there was a concentration-dependent reduction in the number of cells containing inclusion bodies: $51 \pm 4 \%$ and $28 \pm 3 \%$ (mean \pm SD) of the cells contained inclusions at Verapamil concentrations of 100 and $150 \mu \mathrm{M}$, respectively. At 


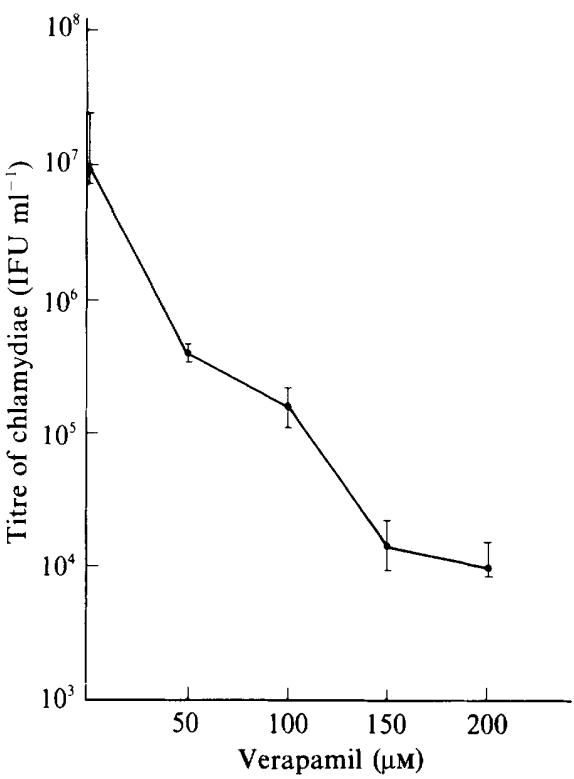

Fig. 1
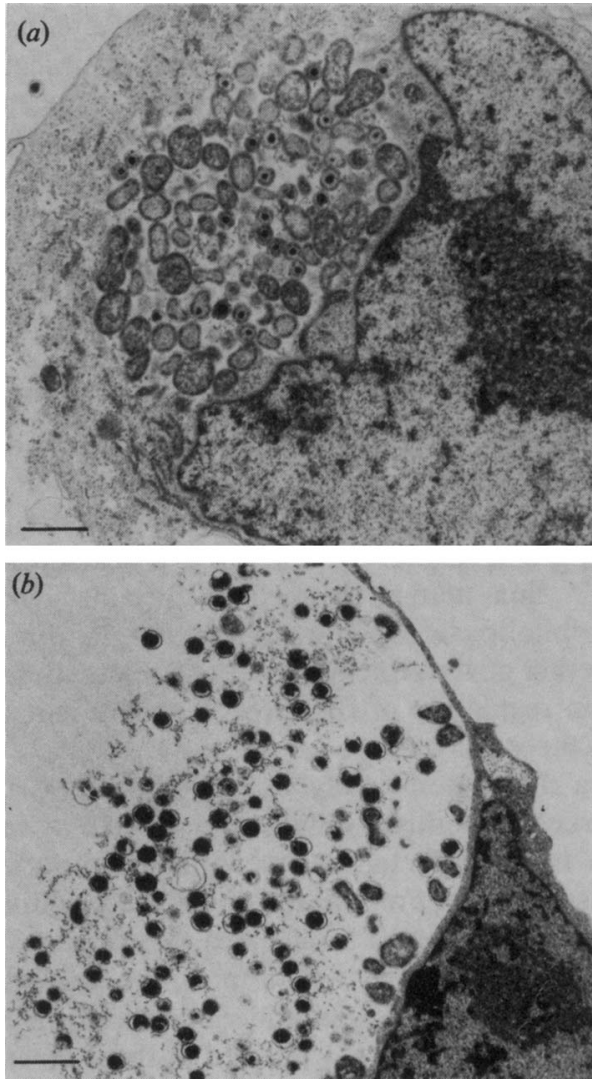

Fig. 2

Fig. 1. Inhibition of the yield of infectious chlamydial particles in BGM cells infected with $C$. trachomatis at m.o.i. $=1$ in the presence of various concentrations of Verapamil. Chlamydial titres were determined $45 \mathrm{~h}$ post-infection; the mean titres from five experiments are given $\pm \mathrm{SD}$.

Fig. 2. Transmission electron micrographs of thin sections of BGM cells infected with C. trachomatis, with (a) $150 \mu \mathrm{M}$-Verapamil added after adsorption, and $(b)$ no addition of the drug. Cells were fixed $45 \mathrm{~h}$ post infection. (a) Cell treated wtih $150 \mu \mathrm{M}$-Verapamil, showing a small inclusion with predominantly RBs. (b) Control: part of a large inclusion body showing predominantly EBs. Bars, $1 \cdot 2 \mu \mathrm{m}$.

those Verapamil concentrations the inclusions appeared smaller than in untreated control infected cells.

Effect of Verapamil on control BGM cells. The effect of various concentrations of Verapamil on DNA synthesis in BGM cells was examined $24 \mathrm{~h}$ and $48 \mathrm{~h}$ after addition of $\left[{ }^{3} \mathrm{H}\right]$ thymidine. The only effect observed was a reduction of $12 \%$ in DNA synthesis at $48 \mathrm{~h}$ with the highest concentration of Verapamil $(200 \mu \mathrm{M})$. No noticeable morphological or cytological change in BGM cells could be detected, at this Verapamil concentration, by light or by electron microscopy.

Electron microscopy. Thin sections of C. trachomatis-infected cells, with or without Verapamil $(100 \mu \mathrm{M}$ or $150 \mu \mathrm{M})$ added after adsorption, were examined with the electron microscope. Three hundred cells were scored for each treatment. Cells containing inclusion bodies were examined and the ratio of EBs to RBs in each inclusion body was determined. No significant difference could be detected in the ratio of EBs to RBs at $24 \mathrm{~h}$ post-infection between untreated and 
Verapamil-treated $C$. trachomatis-infected cells at either Verapamil concentration (about $97 \%$ of the particles were RBs). At $45 \mathrm{~h}$ post-infection, (Fig. 2), the control infected cells showed large inclusion bodies in which $87.6 \%$ of the particles were EBs. In the Verapamil-treated infected cells, there was a decrease in the ratio of EBs to RBs with increase in the concentration of the drug: $43.5 \%$ and $26.8 \%$ of the particles were EBs at Verapamil concentrations of $100 \mu \mathrm{M}$ and $150 \mu \mathrm{M}$, respectively $(P<0 \cdot 01$, Student's $t$-test $)$. Moreover, at the higher concentration of Verapamil most of the inclusions appeared much smaller than those in untreated $C$. trachomatisinfected cells.

\section{DISCUSSION}

It is now generally accepted that $\mathrm{Ca}^{2+}$ and cyclic nucleotides are the major components of an internal signalling system regulating cell activities. Cell injury (Humes, 1986), bacterial and viral attack (Durham, 1978), hormones and many other activities (Berridge, 1975) are mediated by changes in cellular $\mathrm{Ca}^{2+}$ fluxes and distribution. Ward \& Salari (1982) have suggested that rapid $\mathrm{Ca}^{2+}$ flux across the cell membrane, which may lead to the activation of membrane phospholipase $\mathrm{A}_{2}$, enhances prostaglandin synthesis and stimulates cGMP synthesis, which together govern the infectivity of chlamydiae (Murray \& Ward, 1984). Since $\mathrm{Ca}^{2+}$ fluxes are the main regulators of this process, treatment of the host cell with the $\mathrm{Ca}^{2+}$ ionophore A23182 enhances infectivity.

In the present study we were able to demonstrate that the calcium antagonist Verapamil markedly inhibited chlamydial growth at concentrations at which host cell DNA replication was hardly affected. Verapamil, when added at a concentration of $150 \mu \mathrm{M}$ after adsorption, caused an approximately 1000 -fold reduction in chlamydial yield. Light and electron microscopic analysis suggested that there was a reduction in the number of inclusions, and that the differentiation of RBs into EBs was inhibited. A greatly reduced effect of the drug was obtained when it was added only during the adsorption step. It should be noted that the concentration of the drug used in these in vitro studies was more than two orders of magnitude greater than the plasma concentration attained in patients receiving therapy. Verapamil may, however, be of value as a local anti-chlamydial agent.

Recent studies in this laboratory with measles and vaccinia viruses ( $R$. ShainkinKestenbaum, and others, unpublished data) have demonstrated that increased $\mathrm{Ca}^{2+}$ uptake by the infected cells, as well as treatment with Verapamil, strongly reduces viral yield. Other investigators have also demonstrated an inhibitory effect of Verapamil on replication of human cytomegalovirus (Albrecht et al., 1984), Epstein-Barr virus (Nemerov \& Cooper, 1984) and influenza virus (Nugent \& Shanley, 1984). Taken together, these results clearly demonstrate that Verapamil exhibits anti-viral and anti-chlamydial activity in vitro. Chlamydial infections are inherently chronic, often running a prolonged subclinical course. The therapeutic effects of antimicrobial drugs are variable and in many cases these drugs fail to prevent recurrence of the disease, or may leave the patient symptomless, but still infected (Oriel, 1986). Animal model experiments are required to explore the anti-viral and anti-chlamydial potential of Verapamil in vivo, particularly for external or local treatments, alone or in combination with other drugs.

\section{REFERENCES}

Albrecht, T., LI, J.-L., Speelman, D., Ball, R., Nokta, M., Fons, M., Lee, C. H., Steinsland, O., Thompson, W. C. \& CARney, D. H. (1984). Cellular responses to human Cytomegalo virus infection. Birth Defects: Original Article Series 20, 21-34.

BERRIDGE, M. J. (1975). The interaction of cyclic nucleotides and calcium in the control of cellular activity. In Advances in Cyclic Nucleotide Research, vol 6, 1-98. Edited by P. Greengard \& G. A. Robinson, New York: Raven Press.

Caldwell, H. D., Kromhout, J. \& Schachter, J. (1981). Purification and partial characterization of the major outer membrane protein of Chlamydia trachomatis. Infection and Immunity 31, 11611176.

Durham, A. C. H. (1978). The roles of small ions, especially calcium in virus disassembly, take-over and transformation. Biomedicine 28, 307-314.

Humes, H. D. (1986). Role of calcium in pathogenesis of acute renal failure. American Journal of Physiology 19, F579-F589.

LADANY, S. \& SAROV I. (1985). Recent advances in Chlamydia trachomatis. European Journal of Epidemiology 1, 235-256. 
MouldER, J. W. (1982). The relation of basic biology to pathogenic potential in the genus Chlamydia. Infection 10, Suppl. 1, 1-9.

Murray, A. \& Ward, M. E. (1984). Control mechanisms governing the infectivity of Chlamydia trachomatis for HeLa cells: the role of calmodulin. Journal of General Microbiology 130, 193-201.

Nemerov, G. R. \& CoOPER, N. R. (1984). Infection of B lymphocytes by a human herpes virus, EpsteinBarr virus, is blocked by calmodulin antagonists. Proceedings of the National Academy of Sciences of the United States of America 81, 4955-4959.

Nugent, K. M. \& Shanley, J. D. (1984). Verapamil inhibits Influenza A virus replication. Archives of Virology 81, 163-170.

Oriel, J. D. (1986). Chemotherapy, In Chlamydial Infections, pp. 513-523. Edited by D. Oriel, G. Ridgway, J. Schachter, D. Taylor-Robinson, \& M. Ward. Cambridge: Cambridge University Press.

SAROV, I. \& BECKER, Y. (1968). RNA in the elementary bodies of trachoma agent. Nature, London 217, 849852.

SAROV, I. \& BECKER, Y. (1969). Trachoma agent DNA. Journal of Molecular Biology 42, 581-589.

SAROV, I. \& HaIkIN, H. (1983). Human Cytomegalovirus specific $\operatorname{IgA}$ antibodies detected by immunoperoxidase assay in serum of patients with Cytomegalovirus infections. Journal of Virological Methods 6, 161-169.

SHEMER, Y. \& SAROV, I. (1985). Inhibition of growth of Chlamydia trachomatis by human gamma interferon. Infection and Immunity 48, 592-596.

WARD, M. E. (1983). Chlamydial classifications, development and structure. British Medical Bulletin 39, 109-115.

Ward, M. E. \& Salari, H. (1982). Control mechanisms governing the infectivity of Chlamydia trachomatis for HeLa cells: modulation by cyclic nucleotides, prostaglandins and calcium. Journal of General Microbiology 128, 639-650. 